\title{
THE “UNITY OF STATEMENT” AS THE INTERPRETATION OF SPACE: THE CASE OF ARCHEO-PARK IN TURKEY
}

\author{
Nadide Karkiner* \\ Anadolu University, Faculty of Humanities, Department of Sociology, Eskisehir, Turkey
}

\begin{abstract}
The aim of this article is to form a "unity of statement" about an 'Archeo-Park' by using M. Foucault's archeological analysis The article attempts to trace the process of "discursive formation" in the 'Archeo-Park' that is designed from the excavation of "Bursa Aktopraklık Mound" as the space of organized discourses of prehistory, architecture and sociology. As relevant units of discourses, the unity of prehistory, architecture and sociology based on the 'systems of dispersion' of their own statements about the objects in the 'Archeo-Park', exist as a unity of statement for conserving and displaying archeological ruins in their original places as open-air museums. As a follower of this "unity of statement", the 'Archeo-Park' defined as "Developing Cultural Sector at the Bursa Aktopraklık Mound: a Multifaceted Project" as would be the space of both "discursive formation" and "formation of objects".
\end{abstract}

Key words: The unity of statement, Archeo-Park, Archeological analysis, Prehistory, Architecture, Sociology.

Article Info: Manuscript Received: February 6, 2012; Revised: May 25, 2012; Accepted: June 15, 2012; Online: November 30, 2012.

\section{Introduction}

The bold footsteps of history can still be traced in rich archeological sites of Turkey, where various civilizations have flourished over the centuries and left their unique remnants in this magnificent piece of land. As official witnesses in retracing these historically flavored footsteps, numerous archeological studies aspired to grasp a different scent of history in Turkey since the 1950s. KaratepeAslantaş (Çambel, 2010: 131) project of Halet Çambel, which was conducted in the second half of the 1950s, has been a pioneer of open-air museums in the country which aimed to conserve and display archeological ruins in their original places (Eres, 2010: 124). More recently, Diyarbakır-Çayönü project of Mehmet Özdoğan was the pioneer in the 1990 os for the conservation and display of a settlement of a prehistoric period (125). These two projects would be main source of the 'unity of statement' not only for the scholars in archeology and prehistory disciplines but also for interdisciplinary studies. By 'unity of

* Correspondence address:

Address: Anadolu University, Faculty of Humanities, Department of Sociology, Yunusemre Kampusu, 2647o, Eskisehir, Turkey

Telephone: +90-555-9766400

Email: nkargine@anadolu.edu.tr statement' it is mentioned the attempt to form a discourse unity about the conservation and display of archeological ruins in their original places.

The archeological followers of this 'unity of statement' can be seen in a special section of Turkish Academy of Sciences Journal of Cultural Inventory (2010) on "the protection and display of excavated prehistoric sites in Turkey" which covers several contemporary studies in Turkey. Those studies are Çatalhöyük (Atalay et.al., 2010: 155); Lalapaşa Megalithic Monument (Akman, 2010: 167); Așağı Pinar Open Air Museum (Eres et.al., 2010: 183); the Case of 4th Millennium Arslantepe (Frangipane and Mangano, 2010: 201); Așılkhhöyük (Özbașaran et.al., 2010:215); Kanlıgeçit Open-Air Museum (Ar1 et.al., 2010: 229); İzmir-Yeşilova Mound (Derin, 2010: 263) and Bursa Aktopraklık Mound (Karul et.al., 2010a: 241).

Bursa Aktopraklık Mound project (Karul et.al., 2010a: 241) will be delineated throughout this paper for the purpose of presenting the archeological analyses' (Foucault, 1995: 157) of the 'Archeo-Park' it develops, stands out as a traditional follower of both H. Çambel's and M.Özdoğan's studies. Aktopraklık mound in northwest Anatolia is one of the significant examples, represents the spreading process of "Neolithic life style" to the West from Anatolia (Özdoğan and Başgelen, 2007: v11). Lying at the 
intersection of urban, rural and industrial areas, Aktopraklık mound is in Akçalar town of Bursa in Marmara region and is dated to $6000-5000$ B.C (Karul.2007a, 2011a, 2011b). The 'Archeo-Park' project emerged from the excavation of "Aktopraklık Mound" that has been directed and executed since 2004 by Professor Necmi Karul from Istanbul University (Karul, 2007a: 387).

This article is aimed to search a 'discursive construction' of the 'Archeo-Park' as the ultimate aim of "Developing Cultural Sector at the Bursa Aktopraklık Mound as a Multifaceted Project" (Karul et.al., 2010a: 241). While the mound is a unit of prehistoric excavation, the 'Archeo-Park' itself has become the object of a 'discursive construction', that is the 'archeology of knowledge' put forward by Michel Foucault as a method. The archeology of knowledge method refers to "a style of relating to discursive materials" (Hannah, 2007: 86) of prehistory, architecture and sociology in this project. The categories of this method are the "relevant descriptive dimensions" (86) in which "organized discourses' of disciplines above (86) are placed. These categories "can be extremely useful in the task of outlining discursive 'spaces of dispersion" (86).

A discursive formation, in turn, can be described as a provisional unity of discourse whose coherence is attributed to a delimitable range of common objects, subjects, concepts and strategies which have been formed and probably altered through actual discursive events. The result is an account of what Foucault calls 'spaces of dispersion' (Foucault, 1995: 10, Hannah, 2007: 88). By using the key concepts of Foucault's archeology of knowledge in various aspects of Bursa Aktopraklık Mound project, this paper will attempt to trace the process of "discursive formation" in the 'Archeo-Park'.

In the light of the Foucaldian method and its distinctive categories, a question poses itself: how 'Archeo-Park' has "appeared, and has been formed and re-formed as an object within its spaces of dispersion" (Hannah, 2007: 88-89). If the focus is on 'the formation of objects' in the Archeo-Park', it appears both as an object of 'discursive formation' as a provisional discourse and the space of 'organized discourses' of prehistory, architecture and sociology.

The formation of objects in the 'Archeo-park' began with the placement of 200-year-old six wooden houses across the northwest of the mound. Those houses are from the Eskikızılelma village 40 kilometers away from the mound area. Approximately 80 peoples from the village worked in the excavation and reconstruction of wooden houses as seasonal workers more than half of whom were males. A sociological field work was conducted in the village in summer 2009 in order to analyze the aspects of social, economic and cultural participation of villagers in the project (Karkıner and Yeșildal, 2009).

The relevant discursive formation of study is the "multifaceted project" of Karul (Karul et.al., 2010a: 241) itself. To Hannah (2007: 88), Foucault aims to "locate the complex relations that tie units of discourse together within" (88) like prehistory, architecture and sociology in this project. Rather than using '“work', 'author', 'discipline' and 'school' as relevant units of discourse", "Foucault proposes to study 'discursive formations' 'statements' and 'archives'” (Hannah, 2007: 88).

While the Aktopraklık Mound (Karul, 20o7a; Karul, 2011a; Karul, 2011b; Karul, in press) is the archive of the 'Archeo-Park' for the unity of statement, prehistory, architecture and sociology are the relevant units of discourses about 'Archeo-Park' both as the space of other discursive formations. Their statements as discursive phenomenon are specified in the constitution of 'Archeo-Park' as a space in varying time periods. As Foucault suggested, the archeological analysis,

"individualizes and describes discursive formations. That is, it must compare them, oppose them to one another in the simultaneity in which they are presented, distinguish them from those that do not belong to the same time-scale, relate them, on the basis of their specificity, to the non-discursive practices that surround them and serve as a general element for them" (Foucault, 1995: 157).

The "multifaceted project" of Karul (Karul et.al., 2010a: 241) includes the mound and its findings, reconstruction of the first prehistoric farmer house as well as the revival of a Chalcolithic village, cemetery and a traditional village. In the project it is also planned to construct an artificial mound for the education of primary and secondary school students beside the communal areas which comprises the lounge, café and a shop (Karul et.al., 2010a: 243). Therefore, the elements of the 'Archeo-Park' cited above constitute the discursive phenomena of discursive formations of prehistory, architecture and sociology. These discursive formations can be opposed, compared and presented simultaneously and distinguished on the basis of the time period to which they belong.

One can notice practices related to these discursive phenomena. Thus, the archeological description of Foucault "tries to establish the regularity of statements" or discursive formations by "uncovering the regularity of discursive practice" (Foucault, 1995: 144-5). Nonetheless, in the archeological analyses of the 'Archeo-Park', prehistory, architecture and sociology have their own domains and unities, which are "juxtaposed, separated and confront one another" (157). For the 
purpose of discourse unity among them, their "statements different in form, and dispersed in time, form a group if they refer to one and the same object" (Foucault, 1995: 32) as the 'Archeo-Park'. So the statements of prehistory, architecture and sociology are different but related the ruins of mound, the wooden houses from Eskikızılelma village and laborers of excavation that are dispersed in time. Consequently, all of them refer the 'Archeo-Park' that is the space of discourse unity.

The appearance of objects in 'Archeo-Park' during a given period of time is enabled by the "rules of interplay" (Foucault, 1995: 33). That means the finds of mound, wooden houses, first prehistoric farmer houses, Chalcolithic village, cemetery, traditional village, the lounge, café and a shop in 'Archeo-Park' are shaped by "measures of discrimination" (33) according to the methods of prehistoric excavation. They are not only "differentiated" (33) in prehistory, architecture and sociology but are also "manifested" (33) in archeological and historical descriptions and "circumscribed" (33) by archeological, architectural and sociological concepts.

Accordingly, the unity of discourse on 'ArcheoPark' "would be the interplay of the rules that define the transformations of different objects" (33) like the mound and the identification of its findings, wooden houses and the labor of villagers. The gap between the timing of the mound, wooden houses, labor of villagers and modern buildings has a determining factor for the discontinuity between the mound, the wooden houses and laborers The unity of prehistory, architecture and sociology can be based on the "systems of dispersion" of their statements about the objects above (37).

To specify a system of dispersion (Foucault, 1995: 38) among a number of statements defining "a regularity between objects, positions, functionings and transformations" (38) in the 'Archeo-Park', the focus is placed on the discursive formation by avoiding the holistic statements of science, ideology, theory and objectivity. Since the holistic theoretical formations prove inadequate in designating a dispersion of statements of prehistory, art history, architecture and sociology in 'Archeo-Park', 'the rules of formation' (Foucault, 1995: 38) of Foucault's analysis provide discourses, their related objects and statements to disperse in space, not in time. The thematic choices of Karul (2007b) in 'Archeo-Park' are also subjected to "rules of formation" not only as conditions of existence "but also of coexistence, maintenance, modification and disappearance" (Foucault, 1995: 38) of the objects, statements and claims of discourses in space. Concomitantly, the rules of formation of 'Archeo-Park' can be specified as the coexistence, maintenance and modification of findings of the excavation, the first prehistoric farmer house, traditional village with wooden houses and the communal area with the meeting rooms, café and a shop (Karul et.al., 2010a: 243).

Although there is an apparent 'regularity between objects in the 'Archeo-Park' as a space, they are dispersed across time. Yet, all these objects refer to the 'Archeo-Park' for a unity of statement. While the unity of discourse refers to the 'Archeo-Park', the unity of statement has its roots both in personal efforts of Halet Çambel as a pioneer woman archeologist and the work of her in Karatepe-Aslantaş in Adana, Turkey.

Her student M. Özdoğan (2009) summarizes the rules of formation in the work of Çambel as follows:

"She foresees that the villagers need to have a stable
income to ensure the survival of a museum on the
mountain in a forest. In the following years she
encouraged villagers to feed sheep instead of goat in
order to protect the forest; found out the use of root
paints to generate income from weaving 'kilim' to
establish relations with state authorities individually to
open a school, to provide education, construct roads,
and supply water and electricity. At times the outcomes
did not turn out as Çambel had imagined originally. She
could not prevent forest fires and excesses of 'kilim'
weaving; nevertheless the Karatepe-Aslantas model
would constitute a good example of what should be
done or should not be done in an archeological site".

In the work of Çambel, the 'coexistence, maintenance, modification and disappearance' of findings, villagers and other factors form the rules of formation of establishments as in the case of Karatepe-Aslantaş. In an interview ${ }^{1}$, Professor Karul noted their attempt to support the unity of statement formed by Halet Çambel with most of their colleagues in the university.

'Archeo-Park's emergence as an object has its 'temporalities'. It maintains relations with the 'surfaces of emergence on three levels of temporality' (Hannah, 2005: 93). The first is 'the order of appearance' (93) of 'Archeo-Park' both in archeology, prehistory, architecture and sociology as an object of discourse. The second level is 'the different sequences' (93) of 'Archeo-Park' which other archeologists, prehistorians, architects and sociologists have been informed about and acknowledged this genuine attempt. The third one is 'the longevity and duration' (93) of 'Archeo-Park' as a discursive object that could be preserved for numerous years. This point is aptly depicted by Karul (2007b) as follows:

"Continuous evaluations of the Project have been made for its protection and functionality. It will be

\footnotetext{
${ }^{1}$ A personal interview with Prof. Dr. Necmi Karul in June 2010
} 
operationalized by attributing functions to spaces in consideration of the perspective of archeological data and by constructing small ecosystems for the vitalization of the paleo-geography".

Furthermore, he mentioned that the open air museums like Aslantaş-Karatepe in Adana (Çambel, 2010: 131), Çayönü-Diyarbakır (Özdoğan, 2010: 141) and Aşağı Pınar-Kırklareli (Eres et.al., 2010: 183) have also formed a basis for other contemporary studies (Karul et.al., 2010a: 247). However, Aslantaş-Karatepe by Halet Çambel in the Mediterranean region of Turkey has survived as an open air museum since the 1940 s.

Following the rules of formation, one may pose such a significant question inspired by Foucault as what has ruled the existence of Archeo-Park as an object of discourse. The response can be provided by uncovering different dimensions of the constitution of objects. There exist three dimensions of the constitution of objects in a discursive formation (Foucault, 1995: 41, Hannah, 2005: 90). These include the 'surfaces of emergence', 'the temporalities of emergence' and 'the authorities of delimitation'. As this analysis delineates, these three dimensions are visible in the 'Archeo-Park' in the constitution of objects.

The first is mapping 'the surface of emergence' of the Archeo-Park. Thereby, it is assigned the status of an object "in the field of initial differentiation, in the distances, the discontinuities and the thresholds that appear within it for making it manifest, nameable, and describable" (Foucault, 1995: 41). This study suggests that these surfaces of emergence are not the same "for different societies, at different periods, and in different forms of discourse" (Foucault, 1995: 41). Hannah (2005: 92) defines the surfaces of emergence as "specific discursive and institutional sites in which objects first emerged are re-configured". The "Archeopark' as an object of discourse unity has three 'surfaces of emergence': the first is the excavation of Aktopraklık Mound and its findings. The second is the archeological tradition of Istanbul University whose roots go back to Professor Halet Çambel in the field of Prehistory. In Turkey Professor Çambel has been the leading figure in the management of cultural heritage during the 1950s when the conceptual approaches of UNESCO and ICOMOS had not yet been fully formed (Editorial Board, 2010: 137).

The third can be seen in the "cultural heritage management plan of Aktopraklık" mound (Karul et.al., 2010a: 247). The Aktopraklık mound with its three different settlements (Karul, in press: 1, Karul, 2011a: 63); the display and protection of archeological remains; the construction of an "artificial mound" for educational purposes in prehistoric excavations; the prehistoric and traditional revitalization of villages like the wooden houses of Eskikızılelma village; the sociological analysis of seasonal workers in the excavation; the social and economic participation of villagers in the project such as being involved in the communal area, café and the shop which included the meeting center for workshops, displays and accommodation constitute the surfaces of emergence of the "cultural heritage plan of Aktopraklık" mound as the 'Archeo-Park'.

The second dimension "in the formation of objects" is "the temporalities of emergence" (Hannah, 2005: 92). The first "temporalities of emergence" of the 'Archeo-Park' is the Aktopraklı mound excavation which has been continued since 2004 (Karul, 2007a; Karul, 2011a; Karul, 2011b; Karul in press). The other is to include the potential of natural and cultural environment of the surrounding landscape (Karul et.al., 2010a: 242).

The third dimension is the 'authorities of delimitation', which refer to the archeologists "as a body of knowledge and practice" (Foucault, 1995: 42), as the authority which "delimited, designated, named and established" (42) the 'Archeo-Park' as an object. Those are the "subject positions from which individuals have or acquire the right to define and delineate the objects of a discursive formation" (Hannah, 2005: 90). These subject positions are fulfilled by the archeologists for establishing the projects like 'Archeo-Park'.

After examining the 'authorities of delimitation', 'surfaces of emergence' and 'temporalities of emergence' as dimensions for the constitution of the 'Archeo-Park' as a discursive object in a discursive formation, the next section will be dedicated to the 'grids of specification' as its locations in a unity of statement.

\section{The Locations of 'Archeo-Park' in a Unity of Statement}

In the formation of 'Archeo-Park' as a discursive object, 'authorities of delimitation', 'surfaces of emergence' and 'temporalities of emergence' can all influence and, in turn, be influenced by 'grids of specification' (Hannah, 2005: 97) as Foucault identified. The prehistory, architecture and sociology are 'grids of specification' in which 'Archeo-Park' is located as a discursive formation. The grids of specification can be described as the systems where objects of any discourse are "divided, contrasted, related, regrouped, classified and derived" (Foucault, 1995: 42) for the unity of statement. Put differently, the "grids of specification" of the 'Archeo-Park' as an object are the prehistory, architecture and sociology for a discourse unity. So the question arises as to how the set of rules of "Management Plan of Cultural 
Heritage of Bursa Aktopraklık" (Karul et.al., 2010a: 242) are "divided, contrasted, related, regrouped, classified and derived" (Foucault, 1995: 42) for unity of statement. Another question would be how are the archeological remains, the artificial mound, revitalized villages, the wooden houses, laborers, village, communal area, café and shop are divided and related? The answer to these questions will be discussed by analyzing how these "grids of specification" have been represented by the mound, wooden houses and the laborers.

\section{The Aktopraklık Mound: Inside or Outside?}

Having "exterior ridges" is the determining factor in the "Management Plan of Cultural Heritage of Bursa Aktopraklık" (Karul et.al., 2010a: 242). Forming a discursive unity makes it possible for the study to be specific, challenging and underlines the ridges of the 'Archeo-Park' as a real establishment. Therefore, the landscape on which Aktopraklık Mound lies is at the intersection of an economically speculative area produces conflicting interests.

To the north of Aktopraklık Mound are large factories in an industrial area. The settlements in Aktopraklık are named as sites A, B and C. Site C is already discovered during the construction of a factory near the 'protected settlement area' (Karul and Avc1, 2011: 1).

The mound lies on a piece of the land privately owned by the factory. The management of the factory has continuously dumped detritus on a disused part to prevent excavations being conducted. Consequently, there is a virtual struggle between the excavation management and the factory management. Yet, the factory continues to sponsor the lunch provided to the excavation team.

This unique establishment of the Mound as an object for the unity of statement and as a system of dispersion (Foucault, 1995: 38), therefore, presents the 'Archeo-Park' as a place of struggle at the local level. Consequently, the search for a discourse unity has to underline the sets of struggles against international companies, speculators, genetically modified organisms, hybrid seeds and poverty in their social, natural and cultural contexts. This has been the contradiction of societal development from past to present. As a matter of fact, the thoughts of Diederik Meijer as an archeologist supported the continuity of struggles in social, economic, political and cultural development of societies (During (2011: 69) :

"the prime subject of archeology consists of investigating how and why complex societies emerged. Accordingly he taught his students to think about issues such as urbanism, the rise of international trade networks, and state formation in a broad supra-regional perspective."

Moreover, the mound excavation as a sphere of sociological research and a source for female and male leaders among laborers to apply Eres' observations on prehistoric open-air museums of the world is one of the underlying motives of this paper on the 'Cultural Sector in Bursa Aktopraklık Mound'. According to Eres (2010), existing prehistoric open-air museums in the world which number around thousands, feature a wide range of approaches in site management, conservation and modes of display, yet "each site should be considered as a unique case" (119) for potential labor participation and entrepreneurship of villagers. Thereby, the 'ArcheoPark' is established not only inside but also outside the mound, which is the grid of specification of its discursive formation.

\section{Wooden Houses: A Puzzle or a Deconstruction?}

The 'Archeo-Park' project was planned to reconstruct the 150-200-year-old wooden houses in the traditional village. For this purpose, the craftsmen from the Eskikızılelma village deconstructed the wooden houses and reconstructed them in the north of the 'Archeo-Park which resembled a remake of a puzzle. Before deconstruction, each part was labeled by an art historian and architect. As a witness of this process, the author observed that their subsequent reconstruction turned out to be very difficult despite the expertise of the craftsmen. The deconstruction of houses denotes a subversion of traditional dichotomies and the destruction of unity in its parts. Unity here refers to the holism, continuity and the life of villagers who became the prisoners of traditionalism.

However, the reconstruction of houses in the Archeo-Park symbolizes the victory of rupture and discontinuity over continuity and holism. After the remake of the puzzle, a gap emerged between the past and the present by transferring the houses from Eskikızılelma village to 'Archeo-Park'. This poses an important challenge to holistic understanding of history (Sarup, 1995: 74) placing events of history in linear processes. In this sense archeology "disarticulates the synchrony of breaks, just as it destroyed the abstract unity of change and event" (Foucault, 1995: 176).

In the 'Archeo-Park' it is planned to construct six wooden houses as in the traditional village and six cottages as the first prehistoric farmer houses. In addition to these, it is planned to construct four 
houses as the revival of a Chalcolithic village. The communal area will be constructed with a display room, accommodation, café and shops (Karul et.al., 2010a: 247). The discontinuity between the histories of houses means the synchronic placement of houses from different time periods.

In this sense, the excavation of Aktopraklık Mound represents the "holistic" view of history with its methodology and knowledge building; the 'Archeo-Park' continuously reconstructs the gap between past and present through the houses and its spatial support to non-agricultural activities. The unity of statement is inevitable for the continuous reconstruction of the gap. To this aim, the laborers of the excavation have to identify themselves with nonagricultural activities in the 'Archeo-Park'.

\section{The Ridge That Destroys Holism: Excavation Laborers}

Sociology as a 'grid of specification' attempts to determine ridges formed by society. Therefore, "building new institutions at the local level that local people can express themselves and claim for their own needs" (Silva, 2002: 38) is more meaningful for the villagers. In this sense, the 'Archeo-Park' proposes social, cultural and economic advantages for structuring an environment in a non-agricultural development.

Thus the rural space is both defined by "its particular relationship to the land, and, in broader terms, to nature and environment" (Silva, 2002: 37) in agricultural production and as a new environment in a non-agricultural development.

In this sense, the 'Archeo-Park' project (Karul et.al., 2010a: 253) constitutes the objective of nonagricultural development in rural restructuring. In this framework, the villagers left agricultural production for the larger market. Currently, they try to survive with subsistence production and nonagricultural seasonal wage. Still, they see the potential of the 'Archeo-Park' as a social, economic and cultural institution in creating non-agricultural activities (Karul et.al., 2010a: 253). What is striking here that current villagers of the region work in the excavation of three settlements in Aktopraklık mound which has been evaluated as prehistoric villages maintained themselves by agricultural production as first farmers of Marmara region (Karul, 2007a: 387, Karul and Avc1, 2010b, Karul, 2011a: 59).

A sociological field research was conducted between 28 July 2009 and 2 August 2009 (Karkıner and Yeşildal, 2009) in Eskikızılelma village by aiming to understand the viewpoint of villagers as local actors about the 'Archeo-Park' and to reveal male and female leaders who will organize the role of other villagers and laborers. Karul (2009) assumed that those leaders were leading the villagers' social and economic participation in the project. As a specific case, Azime Borazancı is a female leader who gave an interview to a national TV channel about her expectations. She claimed that she could understand the value of the remains she discovered during excavation or washing. Furthermore, she told about the predictions of income generating activities that would determine the degree of their social, economic and cultural participation in the project (Karul et.al., 2010a: 252).

The sociological study enables the villagers to search for their potential in taking part in a new institution. While they work in excavation with picks and trowels, archeology students and archeologists as the 'authorities of delimitation' monitor their work. Seen through a problematic linear thinking, there has always been a distance between the villagers and the archeologists, the architects, the art historians and the sociologists in the project. While this distance was narrow in such a local place as village, it widened in the excavation area. The archeologists exist as the authority of knowledge in the excavation. It the end, the unity of statement of multi-faceted knowledge produced in the 'Archeo-Park' includes a discontinuity and temporal dislocation, which means a discontinuity between the time periods of the mound, wooden houses, prehistoric houses and the villagers as laborers. This causes a temporal dislocation and discontinuity that has always been dominant in the archeological knowledge building of the 'Archeo-Park'.

While the image of equality between the villagers and the archeologists, the art historians, the architects and the sociologists was destroyed in the excavations, the 'Archeo-Park' as a space of nonagricultural development provided the villagers with the means to organize their interests and create new social and economic mechanisms as 'new social actors' (Silva, 2002: 33) of the region. The project not only involves the local population but also places a special emphasis on the municipalities in the region. As can be seen in the different locations above, the 'Archeo-Park' is the space of diverse form of statements of archeologists, architects, sociologists and laborers.

\section{The Space of Diverse Form of Statements}

The establishment of 'Archeo-Park' as the space of the diverse form of statements renders it possible to place the mound, wooden houses, prehistoric houses and modern buildings in the project simultaneously. This is because it is a must to "discover the law operating behind diverse forms of statements, and 
the place where they come from" (Foucault, 1995: 50). These details have been examined in the previous pages clearly. Consequently, the 'Archeo-Park' as a 'multi-faceted project' would be the 'space of practices' and the space of discourse accumulation.

The rules of the 'Cultural Management Plan of Aktopraklık' are defined as "the first farmer house", "revival of a Chalcolithic village", "cemetery", "traditional village of wooden houses" and "the artificial mound" beside the "communal area" (Karul et.al., 2010a: 243). This area comprises the meeting rooms for conferences and exhibitions, lounge, café and a shop (243). All these elements of the 'ArcheoPark' above are "grouped together in distinct figures, composed together in accordance with multiple relations, maintained or blurred in accordance with specific regularities" (Foucault, 1995: 129), which means that it will not be a place, but a space of practices. It also serves as a space of discourse accumulation. One can conclude that the 'ArcheoPark' is the object of the discourse unity and its properties define "a particular level of a practice that causes a multiplicity of statements to emerge as so many regular events" (130). It "also reveals the rules of practice that enables statements (of archeology, prehistory, architecture, art history and sociology) both to survive and to undergo regular modification" (130) in the 'Archeo-Park'.

In attempting to determine a "unity of statement" among the multiplicity of statements about the "Archeo-Park" (Karul 2007b) in the excavation area, Aktopraklık Mound can be taken as the place of 'time intervals' (of houses, laborers and communal area), 'formations' (statements of archeology, prehistory, architecture, art history and sociology), 'vanishings' and discursive 'rule of interplay'. As a starting point of the project it would be the "general system of the formation and transformation of statements" (Foucault, 1995: 130).

Formation of a "unity of statement" necessitates refusing the holistic forms of knowledge that foresee the division of knowledge into parts and spatialization of reason. Hence, the aim of archeological analysis is to define "discourses in their specificity; to show in what way the set of rules that they put into operation is irreducible to any other; to follow them the whole length of their exterior ridges, in order to underline them the better" (Foucault, 1995: 139).

The project of 'Archeo-Park' as an object of discourse originates as a discursive formation along three dimensions. Foucault distinguishes these three dimensions as 'discontinuity', 'temporal dislocation' and "unity of statement". The discontinuity between the forms of knowledge claimed by archeology, architecture and sociology originates from the temporal dislocation of objects and villagers as laborers in the excavation area of the mound. To form a unity of statement, all those varying forms of knowledge disperse in time and space. Furthermore, these varying forms of knowledge do not enjoy privilege over one another.

In case of the 'Archeo-Park', discontinuity enables archeology, prehistory, architecture and sociology as forms of knowledge to discontinue and to rupture, to change and to transform it to an object of discourse.

\section{The 'Object of Discourse'}

The 'Archeo-Park' fulfills the necessary conditions to appear as an “object of discourse". As Foucault suggests:

"The conditions necessary for the appearance of an object of discourse, the historical conditions required if one is to 'say anything' about it, and if several people are to say different things about it, the conditions necessary if it is to exist in relation to other objects, if it is to establish with them relations of resemblance, proximity, distance, difference, transformation-as we can see, these conditions are many and imposing" (Foucault, 1995: 44).

Although the excavation work in the mound is executed in a holistic and continuous discursive practice, 'Archeo-Park' exists 'in relation to other objects' like wooden houses, prehistoric farmer house and Chalcolithic village, cemetery, and the artificial mound beside the meeting center which comprises the rooms for conferences and exhibitions, lounge, café and a shop (Karul et.al., 2010a:243). Moreover, it is established by the "relations of resemblance, proximity, distance, difference and transformation" between the objects cited above. These relations, however, have transformed the area of mound into another place with other objects which have distances and differences among themselves in terms of temporality. As an object of discourse 'ArcheoPark' is conceived with "other objects in its surrounding area”. Thereby, it is the 'Archeo-Park' which will realize the relations with other objects.

One of these objects is the houses aimed to be reconstructed in their original forms near the excavation area after a process of deconstruction in their original places where their protection was impossible (Karul, 2007b). Professor Karul explains this process in the following terms:

"With the study named as Sample Village (ArcheoPark), the aim is the reconstruction of a building or group of buildings which conserve their traditional characteristics (in the village) or in the remains of excavation. This village is not only adapted to the natural environment in its originality, but is also 
established in a certain distance from the archeological remains with the aim of conservation" (Karul, 2007b).

In the 'Archeo-Park' as a space, there occurs the "coexistence of dispersed and heterogeneous statements" (Foucault, 1995: 34) of prehistory, art history, architecture and sociology. Archeologists as the authorities of delimitation govern the division of statements of disciplines above by transforming, arranging and replacing them.

\section{Conclusion}

The 'Archeo-Park', as an object of the archeology of knowledge and the space of unity of statement attempts to practice "a different history of what men have said" (Foucault, 1995: 138) by rejecting the linear form of history that is determining in the excavation of mound. The significance of this attempt lies at the coexistence of localized political struggles and specific power relations (Sarup, 1995: 94) beside other prehistoric excavations, differed in their geographical situation in northwest Anatolia as Karul mentioned (2011a: 63):

"According to their geographical situation, Barçın and
Menteșe are plain settlements. Likewise, Ilıpınar, which
is situated just at the western end of the Lake İznik is a
plain settlement, too. On the other hand, Fikirtepe,
Pendik and Aktopraklık are different. Fikirtepe and
Pendik are in coastal areas, while Aktopraklık is nearly
coastal, but more in a foothill location".

Moreover, "the different stages of occupation at Aktopraklık were not superimposed each other, but rather either shifted horizontally and down slope form one valley ridge to the other opposite" (Karul, 2007: 391-392, cited in Karul and Avc1, 2011b: 1).

Consequently, among other excavations, the specificity of Aktopraklık mound is the 'Archeo-Park' that would be significant as far as the formation of local political struggle is concerned. While the multinational and transnational capital reified the agricultural regions in underdeveloped countries either in the name of support or in the name of restructuring, this project is a significant example of local political struggle which builds new social and economic institutions for the participation of local people as "new social actors" (Silva, 2002: 33) in the region. High costs of agricultural production force peasants to leave agricultural production and seek new income opportunities like working as seasonal wage labourers in varying jobs like archeological excavation (Karul et. al, 2010a: 253) and have been cooperated the establishment of the 'Archeo-Park' (Karul and Avc1, 2010b: 4) as local social actors.
Basically, it is not an alternative institutional structure for the organization of local people, but rather an attempt to include different statements (archeology, architecture, sociology, peasants) to "execute the localized political struggles with specific power relations" of peasants as laborers in the excavation, the mayors, archeologists, architectures, art historians and Professor Karul himself.

This necessitated a multi-faceted perspective or a "peculiar kind of multi-faceted knowledge that surrounds our view of the human condition and human relationships with each other and the wider world" (Darvill, 2007: 446). The multifaceted features of the 'Archeo-Park' represent a new formation in the region. These features include the statements of prehistory, architecture and sociology as well as the participation of villagers, local administrations, municipalities and the archeologists as the 'new social actors'. Furthermore, multifaceted features support the argument that, increasing complexity of societies (During, 2011: 69) will always be the issue of archeology in future.

The original value of this 'multifaceted project' originated in the excavation of Aktopraklık Mound, reiterated itself in Eskikızılelma village and had its outcomes in the 'Archeo-Park'.

Eres' claim about prehistoric open-air museums of the world that "each site should be considered as a unique case" is one of the underlying sources in writing this paper about the 'Cultural Sector in Bursa Aktopraklık Mound'-(Eres, 2010: 119). The other source is the problematization of the archeological knowledge building in this project. The synchronic juxtaposition of objects from different time periods in an excavation area is a discontinuity and necessitates the conceptualization of "relations of resemblance, proximity, distance, difference and transformation" (Foucault, 1995: 44), within three settlements in the Mound and the placements around it. While there is a resemblance and proximity between the different sites of mound, time distance and difference is determining between the objects and they are transformed in a geographical proximity in the 'Archeo-Park'.

In a different perspective Karul called his project "a multifaceted project" (Karul et. al., 2010a: 241) by mentioning on the "coexistence of dispersed and heterogeneous statements" (Foucault, 1995: 34) originated from the time distance and differences between the objects forces the analysis of the 'Archeo-Park' as an object

Therefore, the archeological knowledge building in the 'Archeo-Park' has ethical, social and political implications beside its multi-faceted characteristics as a space. As an 'object of discourse' whereas the 'Archeo-Park' includes different statements of differentiating discursive formations, villagers and 
the people in the surroundings of the excavation area represent linear thinking as evidences of knowledge building process throughout the project.

This study is an attempt to present an archeological analysis (Foucault, 1995) of a unique case for the unity of statements that dispersed in time. Not only the statements but also archeologists, art historians, sociologists, architectures, anthropologists and archeo-botanists are dispersed in time synchronically to reveal "the rules of a practice that enables statements both to survive and to undergo regular modification" (Foucault, 1995: 130). The 'Archeo-Park' would be a place where the Aktopraklık mound is prevented from oblivion but couldn't escape from spatial modification as an object.

\section{Acknowledgement}

I owe a special gratitude to Professor Necmi Karul, from the Department of Prehistory in Istanbul University, who not only allowed me to write about his project named as 'Developing Cultural Sector at the Bursa Aktopraklık Mound: A Multifaceted Project', but also contributed and supported me in writing this article.

\section{References}

Akman, M 2010, 'Lalapaşa dolmeni kazı ve restorasyon çalışmaları (Excavations and restoration work at the Lalapaşa megalithic monument)', TÜBA-KED (Turkish Academy of Sciences Journal of Cultural Inventory) 8(8): 167-174.

Arı, İ, Eres, Z \& Demirtaş, A 2010, 'Kanlıgeçit açık hava müzesi: Trakya'da bir ilk Tunç Çağ iç kalesi (Kanlıgeçit open-air museum: an early Bronze Age citadel in Thrace)', TÜBA-KED (Turkish Academy of Sciences Journal of Cultural Inventory) 8(8): 229-240.

Atalay, S, Çamurcuoğlu, D, Hodder, I \& Moser, S 2010, 'Protecting and exhibiting Çatalhöyük (Çatalhöyük'te koruma ve sergileme)', TÜBA-KED (Turkish Academy of Sciences Journal of Cultural Inventory) 8(8): 155-166.

Çambel, H 2010, 'Karatepe-Aslantaş açık hava müzesi: çok yönlü bir proje (The open-air museum of KaratepeAslantaş: a many sided project)', TÜBA-KED (Turkish academy of sciences journal of cultural inventory), vol.8.nr.8, pp. 131-136.

Darvill, T 2007, 'Research frameworks for world heritage sites and the conceptualization of archeological knowledge', World archeology, vol.39. nr.3, pp. 436-457.

Editorial Board, 2010, 'Kültürel mirasta Halet Çambel açılımı: geçmişe gelecek yaratmak (Featuring Halet Çambel in the management of cultural heritage to secure a future to the past)', TÜBA-KED (Turkish Academy of Sciences journal of cultural inventory), vol.8. nr.8, pp. 137140.

Derin, Z 2010, 'İzmir-Yeșilova Höyüğü'nde yeni bir eğitim yöntemi: zaman yolculuğu (New educational methods at
İzmir-Yeşilova: time travel)', TÜBA-KED (Turkish Academy of Sciences Journal of Cultural Inventory), 8(8): 263-274.

During, BS 2011, 'Fortifications and fabrications: reassessing the emergence of fortifications in prehistoric Asia Minor, in BS During, A Wossink, PMMG Akkermans (eds), Correlates of Complexity, Nederlands Instituut Voor Het Nabije Oosten, 69-85, Leiden.

Eres, Z 2010, 'Özel konu: Türkiye'de tarihöncesi kazı alanlarında koruma ve sergileme çalışmaları (Special section: protection and public display of excavated prehistoric sites in Turkey)', TÜBA-KED (Turkish academy of sciences journal of cultural inventory), vol. 8. nr. 8, pp. 101-102.

Eres, Z, Özdoğan, E, \& Demirtaş, A 2010, 'Așağı Pınar açık hava müzesi: yaklaşım, uygulama süreci ve karşılaşılan sorunlar (Aşağı Pınar open-air museum: concept, implementation and problems encountered)', TÜBA-KED (Turkish academy of sciences journal of cultural inventory), vol. 8. nr.8, pp. 1 83-200.

Foucault, M 1995, The Archeology of Knowledge, Routledge, London.

Frangipane, M \& Mangano, D 2010, 'The exhibition of a mud-brick monumental complex in a stratified mound: the case of $4^{\text {th }}$ millennium Arslantepe (Malatya) (Bir höyükte anıtsal kerpiç yapı topluluğunun sergilenmesi: 4 . binyıl Arslantepe (Malatya) Örneği)', TÜBA-KED (Turkish Academy of Sciences Journal of Cultural Inventory), 8(8): 201-214.

Hannah, M 2007, 'Formations of 'Foucault' in angloAmerican geography: an archeological sketch', in J Crampton \& S Elden (eds), Space, Knowledge and Power Foucault and Geography, Ashgate, 83-106, Aldershot.

Karkıner, N \& Yesildal, H 2009, Bursa Akçalar Aktopraklık höyük kazısı, İstanbul Üniversitesi, prehistorya anabilim dalı öğretim üyesi, Doç. Dr. Necmi Karul başkanlığında yürütülen kazı çerçevesinde 2009 yılında Eskikızılelma köyünde yapılan sosyolojik alan çalışması, Kültür ve Turizm Bakanlığı, Kültür Varlıkları ve Müzeler Genel Müdürlüğü. 28 Temmuz - 2 August 2009.

Karul, N 2007a, 'Aktopraklık: kuzeybatı Anadolu'da gelişkin bir köy', in M Özdoğan \& N Başgelen (eds), Türkiye'de Neolitik Dönem: Yeni Kazılar-Yeni Bulgular, Arkeoloji ve Sanat Yayınları, 387-392, İstanbul.

Karul, N 2009, 'Göçle gelen kültürler', Aktüel arkeoloji, vol. 10, pp. 60.

Karul, N, Avcı, MB, Deveci, A \& Karkıner, N 2010a, 'Bursa Aktopraklık Höyük’te kültür sektörünün oluşturulması: çok yönlü bir proje (Developing cultural sector at the Bursa Aktopraklı mound: a multifaceted project)', TÜBA-KED (Turkish Academy of Sciences journal of cultural inventory), vol.8. nr. 8, pp. 241-262.

Karul, N \& Avc1, MB 2010b, 'First farmers of Marmara', (the word format of article is used in this article sent by Necmi Karul in May 2012, 1-4), actually published in İlgi, Sevgi Baş (eds.), pp. 34-39, İstanbul.

Karul, N 2011a, 'The emergence of neolithic life in south and east Marmara region' in R Krauß (ed), Beginnings-new research in the appearance of the neolithic between Northwest Anatolia and the Carpathian Basin; papers of the International workshop $8^{\text {th }}-9{ }^{\text {th }}$ April 2009, Istanbul. 
Karul, N \& Avc1, MB 2011b, 'Neolithic communities in the eastern Marmara region: Aktopraklık C', Anatolica XXXVII, pp. 1-15.

Karul, N, in press, "Aktopraklık mound".

Özbaşaran, M, Duru, G, Teksöz, D \& Omacan, S 2010, 'Yaşayan geçmiș: Așıklı Höyük (The living past: Așıklı Höyük)', TÜBA-KED (Turkish Academy of Sciences Journal of Cultural Inventory) 8(8): 215-228.

Özdoğan, M \& Başgelen, N 2007, 'Türkiye'de neolitik dönem', in M Özdoğan \& N Başgelen (eds), Türkiye'de Neolitik Dönem: Yeni Kazılar-Yeni Bulgular, Arkeoloji ve Sanat Yayınları, vı1-1x, İstanbul.

Özdoğan, M 2010, 'Çayönü : çanak çömleksiz Neolitik Dönem'e tarihlenen bir yerleșim yerinde koruma ve alan düzenleme uygulaması (Çayönü: protection and site management of a Pre Pottery Neolithic Site)', TÜBA-KED (Turkish Academy of Sciences journal of cultural inventory), vol.8. nr.8, pp. 141-154.
Sarup, M 1995, Post-yapısalcılı ve Postmodernizm, Ark Yayınevi, Ankara.

Silva, JG 2002, 'Local sustainable development, globalization and agricultural restructuring in underdeveloped countries', International journal of sociology of agriculture and food, vol.10. nr.1, pp. 33-39.

Karul N 2007b, Güney Marmara Arkeoloji Projesi (viewed in August

2009: http://www.facebook.com/group.php?gid $=5496712823 \# / \mathrm{t}$ opic.php? uid=5496712823\&topic=3135).

Özdoğan, M 2009, Mehmet Özdoğan'ın Gözüyle Halet Çambel, viewed in August 2009: www.site.mynet.com/arkeolojidunyasi/arkeoloji/idı.htm. 